\title{
LIFE CYCLE DATA ANALYSIS FOR SMART CITIES AND SUPPORT WITH GEOGRAPHIC INFORMATION SYSTEM (GIS)
}

\author{
A. C. Kocalar ${ }^{1 *}$ \\ Niğde Ömer Halisdemir University, Architecture Faculty, Dept. of City and Regional Planning, 52400, Center, Niğde, Turkey - \\ azizcumhurkocalar@gmail.com
}

KEY WORDS: Data Infrastructure \& Integration, Spatial Data and Model Quality, Spatial Database, Spatial Data Mining, GIS.

\begin{abstract}
:
The dynamics of globalization have gained momentum with today's developing technology. So we are now faced with the problems of urbanization (and urban governance), which become more evident than in the old days. As the subject cities, interdisciplinary qualities must always be considered. In the study, too, the focus of the urban area was on the problematic issue of intelligent or smart (especially, transportation) management that remained within this framework. GIS plays a major role in establishing the relationship between all kinds of analyses and visual information in the same environment and in determining the right strategies. For this reason, the use of GIS for decision makers is one of the most commonly used methods for intellectual production in the smart cities concept. The work to be done with this method will be able to be systematically successful and sustainable applications in this way.
\end{abstract}

\section{INTRODUCTION}

\subsection{Issue}

With today's developing technology, the dynamics of globalization have gained momentum. So we are now faced with the problems of urbanization (and urban governance), which become more evident than in the old days.

From this point of view, it is necessary to try to approach a more cautious designer role by going beyond the current approaches, in order to manage the urban area, which is becoming a smart and sustainable way, which is transformed into the competition of urban areas with technology and digital solutions in every respect.

Geographical information systems are playing critical roles for a lot of administrators and decision maker because one of the most important factors of the information systems is the data in the last decades. It is very important to form the data available at the institutions according to an information system logic and to determine new data in the same way. This is a subject with priority for each institution which plans to set up an information system. Reformation of the data by the transformation of the graphical and qualitative data in different formations into formations, in which they can have an affair with each other, is one of the main points of the system. In the announcement, these two subjects be examined generally and according to the conditions of our country, the problems will be determined and suggestions will be put forward about the solutions. (Köktürk, E. and Köktürk, E. 2002)

\subsection{Main scope}

To this end, in parallel with the advances in computer and communication technologies, the fast-paced data processing world is becoming increasingly important. It is the forerunner to develop sustainable approaches in the solutions to the problems of urbanization and urban management, which arise in today's conditions where globalization dynamics are overemphasized.

In addition, as the subject cities, interdisciplinary qualities must always be considered. In the study, too, the focus of the urban area was on the problematic issue of intelligent (especially, transport) management that remained within this framework level.

In this context, while the concept of smart cities is used in the framework, it is now widely tried to develop a viewpoint that is conscious of a neoliberal view or a similar product-oriented approach to the consumption society, but in a more prudent position.

The developed countries had started with "e-government". All data about social life with these approaches are now turned into applications with the electronic restructuring, internet, etc. technology to make it always accessible via their decisions. So that data and information, now play a very important role in every aspect of life, is the inevitable support of correct decisions. Spatial data have an important place in the egovernment approach. Writer had been presented by a proceeding as a trend in smart cities, "in recent developments in urban information toward $\mathrm{m}$-state applications from egovernment, by increasing the size of people's participation". (Kocalar, A. C. 2013-b).

\footnotetext{
* Corresponding author
} 


\section{CURRENT GENERAL ISSUES / FINDINGS}

\subsection{Urbanization and Environmental Problems}

Urban areas and places with daily mobility form an important living space of communities and even living beings on our planet.

\subsubsection{Problems of urban areas and places/locations}

Some of these problems: Migration, population growth, quality of life, limited service capacity, security, etc.

The problems created by distorted; urbanism immigration and overpopulation, the increasing need for different services in the urban environment, that are manifested by the volatility of urban living quality with many other factors. As a result of increasing security violations, cities must be constantly inspected for security purposes as a common living space for human beings and animals.

\subsubsection{Problems of protection of urban environment}

The cities need to be protected also by the parts that form a common living space for human beings and animals. Because of this, due to increased security violations in urban areas, it is necessary to constantly inspect for security purposes. Environment and water pollution, the problem of the settlement in the natural resource reserves, human health-related threats appearing incrementing parameters are increasing day by day. Therefore, it is now imperative that the numerical environments in which people are required to monitor the frequency of independent controls become more and more necessary. Unplanned urbanization, bringing along various infrastructure and related health problems, impair fully modern image we want to see the city today. For this reason, Urban transformation Projects are frequently brought to the agenda in our big cities and various projects are being carried out. (Yağc1, C. 2014).

\subsection{ADMINISTRATIVE ROLES IN MANAGEMENT}

There are some gaps / conflicts / contradictions between the central and local governments' administrative roles (coordinated, disjointed). These problems, which grow increasingly serious in size, take place especially in the areas of responsibility of local governments and central government in sometimes. That is why it is necessary to produce common service solutions within on their premise.

\subsubsection{Institutional Issues}

There are administrative jobs: data collection and conversion, lack of expertise, infrastructure problems, security breaches, etc. However, in the researches of nowadays had been showed that our agencies which provide different services in cities have never been sufficient in terms of data collection and value transformation. Especially the lack of expertise is a reality and infrastructure problems still continue. On the other hand, any security violations may occur can be serious problem areas.

Therefore, the fact that the value obtained from the verbal values is still not very warm. On the other hand, in order to the security breaches in the use of electronic media, providers of value will become increasingly important in different types of initiatives. The first of all, the solutions for institutional issues depends on management with enough money. For example; the lack of expertise, the problems of new infrastructure installations and updates are important previous steps before data collection, conversion and integration, etc. steps, also to be ready for security breaches, etc. in anytime.

\subsubsection{Legal Issues (gaps in the legislation / contradictions)}

As neoliberal policies increase the decisive role on legislation, rapid changes are brought about in the different vacancies and contradictions like as Table 1. in below.

\begin{tabular}{|l|c|c|}
\hline Some Laws names & \multicolumn{2}{|c|}{ Laws Numbers } \\
\hline & $\frac{\text { Current Laws }}{5216}$ & $\frac{\text { Old Laws }}{3030}$ \\
Metropolitan & 5393 & 1580 \\
Municipalities & 775 & \\
Other Municipalities & 3194 & \\
Housing and slum & 5018 & \\
Reconstruction & 5490 & \\
Financial Control & $\ldots$ & \\
Population Services & 2464 & \\
Numbering & $\ldots$ & \\
Financial Structures in & 4856,5302, & \\
Mun. & 5216 & \\
Jobs related to & 5393,2918, & \\
municipalities & 4925 & \\
Zoning Plans & & \\
Urban transportation & & \\
\end{tabular}

Table 1. Current or changed some legislation about related city/region subjects (2007)

\subsection{Utilizing GIS based information systems in urban management}

By dealing with all these problems and to make quick and correct decisions at different levels of authority, both urban administrations as well as for the central government is a problem in itself.

Together with the developing technologies to overcome these problems, some of the GIS based information systems on the agenda are listed below.

GIS based information systems:

1. Tracking systems*,

2. Address information systems,

3. Transportation information systems,

4. Earthquake information systems,

5. Infrastructure information systems**,

6. Urban information systems,

7. Planning information systems,

8. Management information systems,

9. Reconstruction information systems,

10. Immovable information systems,

11. Tax information systems

*GPS and GSM technology also uses in these technological systems. Many transportation firms for vehicle files uses these technological systems in their sectors.

**SCADA uses in these infrastructural information systems with time. SCADA is not an open system so this situation is problem for interactivities. 
It is necessary between them coordination and integration with time, especially in smart cities vision too.

Thus, repeated data entry is prevented and verification quality can be also increased in this way. We can give these benefits, first by highlighting the stakeholders and then the author's short summary of those views by grouping and updating in the direction of the vision of the smart cities.

Stakeholders of smart cities:

1. City citizen (Real person)

2. Companies (Legal entity)

3. Municipal administration and employees

4. Investors

5. Immovable Owners (public, private: real, legal person)

Information management systems, which are designed with different focussed in urban area and used with geography based and, will create smart cities of the future these facilities in above.

Benefits to facilitate perception are grouped with key topics:

1. Services

2. Operation (Network)

3. Planning

4. Coordination

5. Investments

2.3.1 Services: In the subjects provided; bureaucracy is reduced, operations are accelerated. From shared veneers even remotely service procurement will become widespread. Citizens will be happy.

Service and operations are easy, costs are reduced, the quality of service increases. Continuity in service is ensured. (7x24)

2.3.2 Operation (Network): Technical infrastructure, water and natural gas subscriber and network data will be collected instantaneously.

2.3.3 Planning: According to social and demographic facts planning facilities, it is provided.

According to the concrete measures of the future of cities, it is planned.

Prevention against accidents and disasters fast and furious, it may plan things.

2.3.4 Coordination: Sewerage network and other with other infrastructure networks' related plans are more realistic given that can be done, cooperation between the related institutions will be achieved easily. The municipal investment objectives should be shared with all stakeholders be in harmony.

2.3.5 Investments: Have all information about the city. Thus, according to population forecasts and facility capacity necessary investments can be directed.

All decisions about investments are taken faster and more accurately.
2.3.6 Living environment: Thanks to environmental protection and risk mapping creating a healthier and livable environment, it will become possible.

\section{SOLUTION DYNAMICS IN SMART CITIES BY GIS}

A technical framework of some current approaches are given by these chapter.

Urbanization requires finding new landmarks for arriving's in town and this leads to the following:

1. the expansion of urban areas and

2. a narrowing of the opened areas leading to other uses

This is in turn, leads to significant energy consumption and environmental impacts of gases such as carbon monoxide and greenhouse gases. For this; both ecological and technological cities (smart cities) are needed.

If the urbanization is uncontrolled, it is more likely that there will be problems such as inadequate infrastructure, illegal construction and different demographic structures. Such developments all over the world also reveal the necessity of smart cities.

\subsection{A technical overview of the framework of intelligent approaches to urban or spatial-oriented virtual environments}

Urban spaces with daily mobility are an important living space for communities even for living things on our planet. Urban (location awareness etc.) spatially focused virtual environments are becoming increasingly widespread in our everyday life with their different application possibilities. Such urban or spatial-oriented digital environments are increasingly needed for the collection, processing, preservation, and conversion of data into various value-added works.

Especially for the increasingly vigorous urban environments, these needs are increasing rapidly. Their classification (technology used, user population, brand / model, etc.) can be quite diverse and will exceed the limits of this declaration.

Here, only those who have notified the position will be emphasized, as well as access to the sectoral solutions will be examined and then general solutions will be given with titles only.

\subsection{New business models for smart cities}

The need in Europe has led to the formation of European smart cities and communities (European innovation partnership EIP).

The most important task of the EIP is the implementation of innovative and technological solutions in the cities for the formation of sustainable cities. This idea naturally leads to the idea of sustainable control.

Organizations such as the United Nations economic commission housing and land management unit (UNECE), UN HABITAT offices, FGD, City planners organization, Dubai real estate institute, European environment agency, OECD, EBC had decided to organize a joint project in this frame. 
With the concept of smart cities in the project, in order to overcome their implementation difficulties low middle income in countries with economies, it is aimed to pass on the principles and practices of sustainable urban development including that new business models that will enhance technology and management skills. The committee for these studies did not announce the period until 2020.

There are many GIS applications near the Smart Cities concepts or subjects nowadays. In the study, the focus of the urban area was on the problematic issue of intelligent (especially, transportation) management that remained within this framework level.

3.2.1 Urban daily mobility (location notified individual flow) and intelligent services: Urban virtual environments (location statement etc.) are becoming increasingly widespread in our daily life by providing usable applications. The collection, processing and preservation of data in these digital environments creates new and important business areas. So much so that it is increasingly necessary for cities to transform this activity into various value added works.

Service quality is directly related to reliability, precision and up-to-datedness of the data/analysis. During planning process, GIS is applied as an objective and precise tool for analysis, synthesis and decision making phases, replacing planner's ability to use self-initiative. GIS provides accurate and rapid data updating, and thus eases deciding for areas where urgent planning or changes are required.

Utilizing GIS, problem is rapidly defined and urgent solutions are found. The statistical data, which is collected by utilizing remote sensing and geographical information system in transportation planning, is examined with information systems and solutions per locations are produced rapidly. GIS also provides objective and precise analysis for future density projections. (Güvenal, B., Çabuk, A., Yavuz, M. 2005).

3.2.2 Transportation networks with intelligent services: Especially monitoring and security of the transportation network purpose auditing is also highly desirable. In addition, since the needs grow rapidly and diversity, it is inevitable that the solutions are a part of life for urban environments that are particularly populous.

Within a study, "data derived from traffic accident reports in Eskişehir County has been used for transportation planning process, as well as determination of critical locations/points in the city". It is about transportation plan decisions with GIS.

Thus, current transportation plan decisions within the regions with determined critical points has been evaluated. Proposals for redesigning the traffic restrictions has been presented according to the analysis results executed in a GIS environment." (Güvenal, B., Çabuk, A., Yavuz, M. 2005).

Another study had been presented in 4th Highway Traffic Symposium, it was about intelligent traffic flows, named "A decision support systems had been designed for special purpose vehicles towards the prevention of traffic accidents in driving safety for road motor in Motorway and Rubber Wheel". (Kocalar, A. C. 2013-a).
3.2.3 Urban transformation perspectives with GIS:

A study with GIS-approach for smart buildings, "From design to project, Sustainable Building Supervision and Management Model (SYDYM) for Building Construction Process Life Cycle" was named, had been presented as a proceeding in Smart and Green Buildings Congress and Exhibition. (Kocalar, A. C., Takçı, H. 2013-c).

Rapid population growth in our living space is spread and urban renewal is needed by the city's social, economic and physical improvement. Urban transformation has also emerged in order to solve the problems concentrated in the urban depression areas in a coordinated manner. Urban regeneration which in solving urban problems is an important tool of there are a lot of policies and procedures in this regard different from each other, in our country as well as around the world and have been widely discussed, monitored and implemented. Geographic Information System through which pad to use in urban areas will allow you to undoubtedly more accurate conversion.

Especially; obtained with using thematic-based base maps, decision-makers can be taking the lead in making the right decisions. In practice; in the field of urban transformation, geographical information technologies, registration, analysis, synthesis with features decision makers more precise results. Such that; map, linking table documents establish spatial relationships and making it possible to make inquiries. (Yağc1, Ceren 2014.)

3.2.4 Common living spaces and intelligent services aimed at improving: A common living space for people and animals in cities it should be supervised for security purposes. Street and in-building camera and surveillance systems are also widespread today.

The fact that the cities enter into new economic relations, consumption habits and changes in patterns; the emergence of new housing, business and management centers, and most importantly, the growth of physical criteria with parallel to the increase in the urban population, new technological urban infrastructure and public services bring to the agenda as a necessity. (Bozkurt, 2008).

Here, in the post-modernization, the use of new technologies in these kind of fields also have to increase over time rapidly.

\section{REALITY FOR GIS APPLICATIONS}

Geography Information Systems (GIS) had been used as general title for City/Urban Management Systems (CMS/UMS) and/or Spatial Information Systems (SIS).

They are using depends on the aiming areas in these work.

\subsection{Overview of spatial information system components}

Since spatial data is also an important part of the e-government approach, the information content system components (hardware, software, data, institutional structure, human resources, rules, etc.) should be considered as a whole.

In view of the authors' work, visualizations will be made clearer through the following three separate tables. (Köktürk, E. and Köktürk, E. 2002). 
4.1.1 General and technical cost problems according to the contents of the components in the systems:

\begin{tabular}{|c|c|}
\hline Jobs in total cost & $\begin{array}{c}\text { Distribution of } \\
\text { load }(\%)\end{array}$ \\
\hline Consultancy & 5 \\
Preparing & 5 \\
Hardware & 10 \\
Software & 15 \\
Others* & 65 \\
\hline
\end{tabular}

Table 2. Distribution of load of jobs for every components within total cost. (Köktürk, E. and Köktürk, E. 2002).

Others item in Table 2. in above is covering identification, compilation and structuring of data.

\begin{tabular}{|c|c|}
\hline $\begin{array}{c}\text { The main system } \\
\text { components }\end{array}$ & $\begin{array}{c}\text { Average life span } \\
\text { (min.-max. in years) }\end{array}$ \\
\hline Life of hardware equipment & $1-2$ \\
Software life & $5-10$ \\
Data life * & 50 \\
\hline
\end{tabular}

Table 3. Average life span of system components. (Köktürk, E. and Köktürk, E. 2002).

Data life is more than others in Table 3. but it is not certain for every systems no doubt.

4.1.2 Related subjects with distributions of uses for spatial information system: The areas and rates of use of data constructed in a spatial information system are as following Table 4 in below.

As writers, Spatial data gain an important position in various social activities, and because of these characteristics "change values" are stronger than the old ones. Increasing use values of spatial data give rise to increasing exchange values. (Köktürk, E. and Köktürk, E. 2002)

\begin{tabular}{|c|c|}
\hline Related subjects & Distribution (\%) \\
\hline The central inst. of the state & 6 \\
\hline Local institutions & 20 \\
\hline Transport sector & 4 \\
\hline Telecommunication & 19 \\
\hline Technical infrastructures & 22 \\
\hline Education & 2 \\
\hline Spatial marketing & 4 \\
\hline Construction sector & 5 \\
\hline Cartographic studies & 5 \\
\hline Land valuation & 9 \\
\hline Private sector and others & 4 \\
\hline
\end{tabular}

Table 4. Related subjects with distributions (\%) for spatial information system. (Köktürk, E. and Köktürk, E. 2002).

There are some steps for information systems of data processing in Table 5. in below.

But especially, it is necessary to transform it into form (or data conversion to required form).

\begin{tabular}{|c|c|}
\hline \multicolumn{2}{|c|}{ Some data processing steps } \\
\hline 1 & to be obtained \\
\hline 2 & be processed \\
\hline
\end{tabular}

\begin{tabular}{|c|c|}
\hline 3 & Configurations \\
\hline 4 & $\begin{array}{c}\text { in the course of presentations } \\
\text { (according to requirements) }\end{array}$ \\
\hline
\end{tabular}

Table 5. Some steps for data processing of information systems (Köktürk, E. and Köktürk, E. 2002).

There are some critical points in these systems according to writers (Köktürk, E. and Köktürk, E. 2002):

1.First of all, heterogeneous properties will be dominate in the related hardware and software structures.

2.The concept of "exchange of data" takes precedence but for "changeability" it is also seen that "transformation" may be necessary.

The cost of the collection and reformation of the data according to the system logic is nearly $65-70 \%$ of total cost of an information system about residential subjects. It is important to be aware of that point because that ratio is generally not known. On the other hand, data sharing between the institutions and the units is also another problem. It gets more difficult to create the data base of the information systems about the residential subjects under the working conditions with institutions and managers that are tight about data sharing. To put forward the rules and conditions of data sharing, to accelerate and to cheapen the data flow are gaining importance for the expectations of the information systems to come true. (Köktürk, E. 2002).

\subsection{Urban transformation with GIS}

With a master thesis, (Yağc1, Ceren 2014.) using GIS facilities in urban transformation studies, analytical data and images that directly or indirectly affect decision-making mechanisms can be used in below:

1. location,

2. geological situation,

3. state of active faults,

4. soil land class tribe,

5. Urban land use equilibrium,

6. slope

7. bond,

8. cadastral status,

9. zoning situations,

10. environmental plans,

11. transport,

12. infrastructure,

13. temporal change and environmental

Using these parameters, the urban transformation phenomenon in the thesis was examined by further realizing the urban transformation of Meram District Altinhamle. In an another papers, "transfer of property and development rights in applications of development plans" by GIS used is possible. (Kocalar, A. C. 2016-b) Firstly, the City Information Management System must be established in a city by the municipality, before it is necessary to start urban transformation studies, etc. For that the infrastructure information, integration with other information about the land, technical infrastructural cadastral information must be ready to use in different urban studies. 
Urban management with City Information-Management Systems(CIMS/UIMS): These kind of facilities in below can be provided with for all urban data, using the possibilities of GIS technology, in the urban (transportation, management, transformation, etc.) projects: Storage, information access, interrogation, analysis, decision making, reporting, visual presentation of results with thematic maps.

\subsection{Natural resources with GIS in regional studies}

There is a proceeding about water resources in Sivas and planning through the apparent effects of climate change (Dams and Ponds and Irrigation Channels) in the UZAL-CBS 2014. (Kocalar, A. C. 2014-f.)

\section{COMPLEXITY EVALUATION FOR DATA PROCESSING IN GIS}

There are very different data structures (graphical, verbal) in GIS, so that this complexity in data processing are important with all components: Data Types/Structures/Resources/Software

\subsection{An overview of the computer architecture basics}

But first of all, an overview of the computer architecture basics with hardware, software and database components are in Table6. in below. Operation systems and application software depends on hardware firms in the similar operating principles. GIS components depends on issues in all these architectures.

\begin{tabular}{|c|c|c|c|}
\hline $\begin{array}{c}\text { Data } \\
\text { structure }\end{array}$ & $\begin{array}{c}\text { System } \\
\text { Hardware } \\
\text { Usage / } \\
\text { Number of } \\
\text { users }\end{array}$ & $\begin{array}{c}\text { Data model } \\
\text { storage / } \\
\text { presentation } \\
\text { environment }\end{array}$ & Transactions \\
\hline $\begin{array}{c}\text { File - } \\
\text { Core } \\
\text { (Jet) }\end{array}$ & $\begin{array}{c}\text { Personal } \\
\text { Computer }\end{array}$ & $\begin{array}{c}\text { Personal Files } \\
(. m d b, \text {.dbf, }\end{array}$ & $\begin{array}{c}\text { Transactions in } \\
\text { single personal } \\
\text { computer }\end{array}$ \\
\hline $\begin{array}{c}\text { Client - } \\
\text { Server }\end{array}$ & $\begin{array}{c}\text { Multi-user } \\
\text { but without } \\
\text { Internet }\end{array}$ & $\begin{array}{c}\text { Central server } \\
\text { files / in } \\
\text { network }\end{array}$ & $\begin{array}{c}\text { Terminals access to } \\
\text { Central server for } \\
\text { operations in } \\
\text { network }\end{array}$ \\
\hline $\begin{array}{c}\text { Client }- \\
\text { Web } \\
\text { Server }\end{array}$ & Multi-user & Central web \\
with Internet & server files / in & $\begin{array}{c}\text { Terminals access to } \\
\text { Central server for } \\
\text { operations in } \\
\text { Internet }\end{array}$ \\
\hline
\end{tabular}

Table 6. Overview of computer architecture basics.

\subsection{GIS data components (data models, types / structures)}

GIS database software depends also on issues in all these four data models in Table 7. in above.

\begin{tabular}{|l|}
\hline Data models \\
\hline Relational \\
\hline Hierarchical \\
\hline Network \\
\hline Object-based \\
\hline
\end{tabular}

Table 7. Classification of database software according to data models.
Graphical software depends on Graphical data structures are in Table 8. in below.

\begin{tabular}{|l|l|l|}
\hline Asset information & \multicolumn{2}{|l|}{ Data type / structures } \\
\cline { 2 - 3 } & Complex & Topological \\
\hline $\begin{array}{l}\text { Data structure / } \\
\text { database }\end{array}$ & $\begin{array}{l}\text { Coordinate } \\
\text { information }\end{array}$ & $\begin{array}{l}\text { Geometric } \\
\text { relations with } \\
\text { coordinate } \\
\text { information }\end{array}$ \\
\hline Storage & Stack & Flexible \\
\hline Repeat records & not Optimum & Optimum \\
\hline Data associations & Unrecordable & Recordable \\
\hline Data Analysis & Difficult & Easy building, \\
\hline Data types & $\begin{array}{l}\text { Parcel, } \\
\text { etc. } \\
\text { contents. }\end{array}$ & $\begin{array}{l}\text { building but } \\
\text { with contents. }\end{array}$ \\
\hline $\begin{array}{l}\text { Additional tools } \\
\text { (Algorithms) }\end{array}$ & Required & Are not required \\
\hline $\begin{array}{l}\text { Data model } \\
\text { presentation }\end{array}$ & $\begin{array}{l}\text { Desktop } \\
\text { environment }\end{array}$ & $\begin{array}{l}\text { Network and } \\
\text { Internet }\end{array}$ \\
\hline $\begin{array}{l}\text { CAD data } \\
\text { integration }\end{array}$ & Yes, easy & $\begin{array}{l}\text { Yes, } \\
\text { difficult but }\end{array}$ \\
\hline $\begin{array}{l}\text { Reporting, } \\
\text { Querying }\end{array}$ & A little difficult & Easy \\
\hline Sample software & & Arc Info CBS \\
\hline
\end{tabular}

Table 8. Simple comparative analysis of systems for producing digital maps specific to cartography study area.

Data components (data streams, structures, resources, database, etc.) with application software in GIS are important, so they are given by Table 9 . without hardware in easy way in below.

In this Table 9., only graphical data and graphical software (Complex, Topological) are shown in very basically. But there is a critical point about data processing related with data types in GIS.

\begin{tabular}{|c|c|c|c|c|}
\hline \multicolumn{4}{|c|}{ GIS Data Types / Constructions / Resources / Software / } \\
Components
\end{tabular}




\subsection{Critical points (different data types/structures) in GIS}

As there are different data structures (graphical, verbal) in GIS, so that this complexity in data processing must be decreased with the design of systems.

In the Client - Server (network type, multi-user) systems structure, very useful with this approach. The server part is attentive and regular, increasing the quality of data and service with high-level control.

This system structure are also used in advanced GIS environments quite more. Thus, it is possible to use with graphics data and verbal data on the same server. These situation were also taken advantages like a list in below:

Advantages of storing and using graphical and verbal data in the same database in advanced GIS environments are:

- Query with geographic data sql statements

- Min. data with max. questioning

- Editing user transport rules

- presenting sneaky by filtering data

- Providing convenience, flexibility and security in data presentation on the Internet

- Relation of graphics and verbal data

5.3.1 Vendor specific technology information (Arcs DE and Oracle SDO): For example, ESRI Arc Info / Arcs DE and Oracle SDO database systems and Geographic databases created by ESRI products are called Geodatabase.

Geodatabase specific information:

In Arcs DE technology, non-graphical (verbal, attribute, tabular) data is easily managed by being stored in a relational database, and the management convenience provided by such use is superior to this product. Databases can be selected differently for personal use (.mdb) and for multiple uses (Oracle, MS SQL, IBM DB2, Informix). (While SDE technology is used with ESRI products, but other GIS software such as Geomedia and MapInfo cannot use SDE technology.)

Advantages of geodatabase data modeling:

1. Regular configuration for data (quick access to data, ease of editing, updating and correcting with interlearner relationships).

2. Better definition of geographical objects, simple geometric shapes (point, line, multiline, closed area) as well as curves, curves, etc. in shape, etc. also ease of arrangement, update and correction.

3. In the same database, related data (vector, raster, TIN, address descriptions) can be placed and managed.

4. It provides easy-to-use data editing and versioning capabilities within the authority of the Internet.

5.3.2 Open approach (OpenGIS Consortium-OGC): Open GIS was announced in 1994. ESRI and Oracle were also entered into this consortium in 1997. OGC has been supporting with related studies with Open GIS Reference model by many workgroups in OGC's issue way. (Buehler, K. 2003).

\subsection{Data processing in GIS-design in Internet}

Compilation of data from sources, transfer into the computer environment, analyze, process, convert information and take part in GIS require very good planning.

The quality of the data, specifications, standards, formats, compilation methods, sensitivities, etc. should be considered in detail during system design.

\subsection{Automatic data integration in cartography mapping periods}

Data must be also smart data in the GIS in data productions and processing operations period as suitable with data specifications, standards, formats, compilation methods, sensitivities in high quality.

Drawings should be defined as which kind of draw (for examples; building, road, slope, channel, lake shore, rainwater grate, garden border, etc.).

\subsection{Geo-referencing systems standards}

There are also many geo-referencing systems standards, some of them used in GIS ready-systems and maps were produced in institutions since 1895 . Then systems standards were changed with 1942, 1953, 1954. The country coordinate systems were accepted by mapping law regulation in Turkey, 1974.

But after 1980, many local coordinate systems were used with plans $(1 / 1000,1 / 2000,1 / 5000)$ in local authorities and institutions.

The selected coordinate system for GIS graphical data will also require some transformations between coordinate systems.

\subsection{Data exchange format standards}

The different data processing methods and the different software's produce different formats for geographic graphics data, raster data and also verbal data (registration records, etc.). So that many of data need to be exchange while using.

There are also defined standards for these data which depends on different countries in differently. (DIGEST is for ABD and NATO countries.)

\subsection{Data compilation}

Data comes from different sources, then analysed with different criteria's (in last section in above) and integrated in to the GIS in compilation period.

After coordinate exchanging, data integrity operations between map booklets takes also more time in this period.

(For examples: building, road, slope, channel, lake shore, garden border type objects' shapes etc.)

\subsection{Methods in GIS}

As a summary, methods can be given by shortly in here. For example, ownership records needs to be correction operations. 
Methods are used with GIS in below:

1. Data compilation

2. Database administration

3. Position determination

4. Monitoring and analyzing

5. Human resources management

6. Financial resource management

7. Risk management

8. Time and resource management

5.9.1 Data compilation methods: These questions must be asked in this period in below:

1. Which data will be compiled?

2. From which sources data will be compiled?

3. What will be the sensitivity and the quality?

4. Which tools will be used?

5. How much resources will be used?

6. How much staff will be used?

7. What time will take place?

Operation steps in this period will be defined after answers to these questions.

5.9.2 Data administration methods: Data administration methods depends on data quantity and dimension.

Important steps in data administration are in below:

1. Data security (intruders, energy droppings, etc.)

2. Data sharing rules (depends on users)

3. Data vendors' producers' administrative levels (users authorities and responsibilities)

4. Data presentation model (in web servers, etc.)

5. Data editing, updates, etc.

\section{CONCLUSION}

Analyses that can take a very long time with traditional methods, it can be done much more simply and quickly with GIS.

For smart cities on GIS -based, a brief summary of what is expected or advised can be presented as follows:

Pre-planning for smart cities (and cities) and instant / continuous / uninterrupted-7/24 monitoring determination of priority sectoral areas.

For examples: Transportation network etc. sectors are also used for control purposes (instant / continuous / uninterrupted-7/24) monitoring and security purposes, continuous improvement in over time.

Critical data on these sectoral areas will be collected institution / organization and non-governmental organizations and their authorities sharing the data at the border, producing new data / reports sharing with the public,

Sample applications to be developed with working together to find solution proposals need to identify the problems in the big data and information urban focussed, security areas in country or international level.
And the most importantly, scientific and commercial activities which are aimed at contributing to the acquisition of different and new values are increasingly valued by safely processing existing data in the public.

The support of Geographical Information Systems, which provide the infrastructure of the urban systems in which such applications take place, also maintains its importance seriously in today's rapidly developing conditions.

Use of the terrestrial-spatial data analysis a more detailed framework should be established for social purposes.

Acceptance and dissemination of data standards will bring new possibilities to work and practice in particularly.

These cross-cutting issues were evaluated in detail in terms of data analysis on a few examples (Traffic management, urban management and urban transformation, etc.)

A conclusion has been drawn that such multidimensional discussions of interdisciplinary will be useful both for those studies and it is thought that the common results will provide enriching contributions to the smart city framework approach.

In the future; by using geographic information systems, alternatives which was put forward, (like minimizing in accident risks, etc.) the findings based on scientific studies that can be carried out for different purposes should be tried to be sampled.

Here, post-modernization and the use of new technologies in the urban studies fields also have to increase over time.

It is possible to use GIS techniques more effectively by working together with many disciplines in different issues to smart cities in the future.

Some disciplines are related with GIS and also smart cities in below:

1. Computer science and data science

2. Research and planning

3. Mathematics

4. Statistics

5. Cartography

6. Geodesy, Photogrammetry, Survey, Remote sensing

7. GPS technologies

8. Constructing engineering

9. Other disciplines (meteorology, city and regional planning, property evaluation management, traffics, first aid, etc.)

\section{ACKNOWLEDGEMENTS (OPTIONAL)}

Acknowledgements of support for the paper are welcome to Computer Engineer (Data Scientist) Şaban Dalaman.

\section{REFERENCES}

Bozkurt, İ. M. 2008. 19.yy Kentiçi Toplu Ulaşımda Modernleşme ve Yeni Teknoloji Kullanımi: İstanbul Örneği, Selçukludan Cumhuriyete Şehir Yönetimi, Ed. Erol Özvar, Arif Bilgin, Türk Dünyası Belediyeler Birliği, İstanbul. 
Buehler, K. 2003. Open GIS Reference model.

Kocalar, A. C. 2013-a. "Karayolunda Motorlu ve Lastik Tekerlekli Özel Amaçlı Araçların Sürüş Güvenliğinde Trafik Kazalarının Önlenmesine Yönelik Bir Karar Destek Sistemi Tasarımı", 4. Karayolu Trafik Sempozyumu, Ankara, 08-0910.5.2013.

Kocalar, A. C. 2013-b. "E-Devletten M-Devlet Uygulamalarına Doğru Kentsel Bilişimdeki Son Gelişmeler ve Halkın Yönetime Katılım Boyutunun Arttırılması", The First International Symposium on Digital Forensics and Security (ISDFS), Elazı $\breve{g}$, 20-21 May 2013.

Kocalar, A. C., TAKÇI H. 2013-c. "Tasarımdan Projeye, Yapı İnşaat Süreciyle Yaşam Döngüsüne Yönelik, Sürdürülebilir Yapı Denetimi ve Yönetimi Modeli (SYDYM)", Akıllı ve Yeşil Binalar Kongresi ve Sergisi, Gazi Üniversitesi Mimarlık Fakültesi, Ankara, 23-24.5.2013.

Kocalar, A. C. 2014-f. "Sivas'ta Hayat Bulan Su Kaynakları ve İklim Değişiminin Görünen Etkileri Üzerinden Planlamanın Vazgeçilmez Hafifliği (Baraj ve Göletler ile Sulama Kanalları)", Uzaktan Algilama-CBS Sempozyumu (UZAL-CBS 2014), 14 16.Ekim.2014, YTÜ, İstanbul.

Kocalar, A. C. 2016-b. "İmar Uygulama Araçlarından 'Mülkiyet ve İmar Haklarının Aktarımı' Modeli (MIHAM)”, 6.CBSUZAL 2016 Sempozyumu, Çukurova Üniversitesi, Adana, 57.Ekim. 2016

Köktürk, Erol, Köktürk, Erdal, 2002. "Convertion and Exchange Problems of the Data in Geo-Information System", GIS 2002-International Symposium on Geographic Information Systems, Istanbul-Turkey, s: 287-300, September 23-26, 2002.

Güvenal, B., Cabuk, A., Yavuz, M. 2005. "Trafik Kazaları Verilerine Bağlı Olarak CBS Destekli Ulaşım Planlaması: Eskişehir Kenti Örneği”, Harita ve Kadastro Mühendisleri Odası, Mühendislik Ölçmeleri STB Komisyonu 2. Mühendislik Ölçmeleri Sempozyumu, 23-25 Kasım 2005, İTÜ - İstanbul.

Güzel, G., 1998. Türkiye Koşullarında CBS/KBS Olușturulabilmesi için Yazılım Araștırması ve Tasarımı, Doktora Tezi, Yıldız Üniversitesi Fen Bilimleri Enstitüsü, Jeodezi ve Fotogrametri Anabilim Dal1, İstanbul.

Güzel, G., 2007. Coğrafi Bilgi Sistemleri, Yönetim Bilgi Sistemi ve Belediye Uygulamaları, Forart Matbaacılık.

Yağc1, C. 2014. Kentsel dönüşüm projelerinde fiziksel değişimin coğrafi bilgi sistemi (CBS) yoluyla araştırılması, Selçuk Üniversitesi, FBE, Harita Mühendisliği Anabilim Dalı, Yüksek lisans tezi, Konya. 